\title{
Sharing aquatic genetic resources across jurisdictions: playing 'chicken' in the sea
}

\author{
Fran Humphries ${ }^{1}$ (D)
}

Accepted: 15 May 2018 / Published online: 24 May 2018

(C) Springer Science+Business Media B.V., part of Springer Nature 2018

\begin{abstract}
International regimes regulating access and benefit sharing were originally designed to promote conservation and fairness objectives concerning the use of the world's biological resources for their genetic material value. These regimes determine from whom permission is required to take the resources and who obtains the benefits of their use. They have evolved separate frameworks in three distinct jurisdictional areas-within national jurisdiction, beyond national jurisdiction and in the Antarctic Treaty Area. This article argues that if these regimes continue to evolve separately, there is a strong temptation for countries to play 'chicken' with biological resource governance through forum shopping or opting out of agreements that do not suit their political ends. Using game theory and a transgenic tilapia fish example incorporating genetic material from the three jurisdictional areas, it illustrates the legal and ethical dilemmas that can arise from the territorial (jurisdictional) approach to access and benefit sharing - to the detriment of fairness and conservation in tilapia's countries of origin. Tilapias are known as the 'chicken of the sea' because they dominate global farmed production and developing countries depend on them as their primary source of protein, livelihoods and trade. This means there will be serious consequences if the regimes do not achieve their fairness and conservation objectives for sharing their genetic material. This article concludes that a purpose-driven cooperative governance approach can sidestep the game of chicken and promote fairer and more conservation focused outcomes than the current jurisdictional approach for the developing country providers of migratory aquatic resources.
\end{abstract}

Keywords Access and benefit sharing - Aquatic genetic resources - Tilapia aquaculture · Technology transfer $\cdot$ Convention on biological diversity $\cdot$ Law of the sea

Fran Humphries

frances.humphries@griffith.edu.au

1 Griffith Law School, Griffith University, 170 Kessels Road, Nathan, QLD 4111, Australia 


\section{Introduction}

'Access and benefit sharing' or ABS is an evolving international concept that arose out of the Convention on Biological Diversity (CBD) for the purpose of regulating access to biological resources for their genetic material potential (such as biodiscovery) and sharing the benefits from their use. Negotiators originally intended the concept to create economic incentives for conserving and sustainably using biological resources by requiring users to compensate the providers who bear the costs of the resources' conservation (Lawson 2012). Benefit sharing can take many forms including monetary benefits or technology transfer and capacity building of the countries entrusted with their conservation. Global cooperation to develop national regimes implementing the international ABS concept theoretically ensures that the burden of conservation does not fall disproportionately on the shoulders of biodiverse rich/economically poor countries, from where the majority of the resources originated (see Frison et al. 2012).

ABS regimes of relevance to aquatic biological resources are evolving in three separate jurisdictional areas-within national jurisdiction, areas beyond national jurisdiction (ABNJ) and the Antarctic Treaty Area (Humphries 2017a). This article uses the fish tilapia as an example of challenges that may arise for research and development in developing countries if governance of aquatic genetic resources continues to evolve using the jurisdictional/territorial origin of the genetic resource as the trigger for technology transfer obligations. Specifically, it uses a hypothetical example based on current transgenic techniques for tilapia product development to illustrate the impact of multiple governance regimes on fairly sharing genetic resource technologies that are sourced from different jurisdictional areas. Tilapias, commonly referred to as the 'aquatic chicken', are the second most important group of global farmed fish after carps (FAO 2017; Khaw et al. 2008). Tilapia culture is dominated by one species, Nile tilapia (Oreochromis niloticus), which accounts for 90 per cent of all tilapia cultured outside their native Africa (Tran et al. 2011). It provides a good case study because developing countries produce over 90 per cent of the word's aquaculture product and 80 per cent of tilapias and rely heavily on this species for food security and trade (Wood and Mayer 2007; FAO 2016).

The remainder of the article argues that there is a strong temptation for countries to play 'chicken' with biological resource governance by opting out of international agreements that do not suit their political ends at the expense of others in the global community. It concludes that a purpose-based cooperative approach evolving under agreements administered by the Food and Agriculture Organization, World Health Organization and World Trade Organization offers a new set of rules for the game of chicken. These new rules could have future relevance to the sharing of knowledge and technologies necessary for aquatic genetic resource conservation, product development and capacity building in developing countries.

\section{Multiple frameworks governing the world's biological resources}

International regimes do not directly regulate biological resource transactions. These regimes provide agreed frameworks or minimum standards that countries can implement under national laws regulating the use of resources within their jurisdictions. Determining whether access, benefit sharing and technology transfer obligations under various international instruments apply to a given genetic resource depends on whether the physical 
sample $^{1}$ originated within national jurisdiction, ABNJ or in the Antarctic Treaty Area. In other words, jurisdictional origin is the default approach for determining whether a given resource falls within a particular technology transfer regime. Determining their origin might be relatively clear for terrestrial resources within national jurisdiction that arguably have more limited independent movement and centuries of documentation and research. However, it is less clear for trans-jurisdictional aquatic genetic resources located in ABNJ and the Antarctic Treaty Area or resources in ex situ facilities for which the genetic resource has multiple or unknown origins. Consistency across jurisdictional areas is problematic because there are no distinct ABS regimes currently in the ABNJ or Antarctic Treaty Area, but rather a patchwork of access and technology transfer rights and obligations. The international community is currently negotiating an ABS framework for ABNJ as part of a proposed Implementing Agreement under the United Nations Convention on the Law of the Sea (UNCLOS) (United Nations General Assembly 2015). Depending on negotiations, the new agreement could either clarify rules for cross-jurisdictional aquatic resources or develop an additional layer of complexity.

The ABS concept under the CBD highlighted a shift from treating genetic resources as the common heritage of human kind towards recognising the rights of countries over those resources and the regulation of their use (Aoki and Luvai 2007). The concept largely arose from conflict over terrestrial genetic resource exchange, which produced the predominant territorial and transactional approach to ABS regimes. As a generalization, when the CBD was under negotiation, terrestrial resource conflict was between 'South' developing nations where the majority of genetic resources for global crops originated and 'North' developed nations who profited from technologies arising from their use (Frison et al. 2012). Access and benefit sharing was an attempt to create fairness and economic incentives for conserving and sustainably using biological resources and their genetic diversity by requiring users of genetic resources to compensate those who bear the cost of conserving and providing genetic resources (Oberthür and Rosendal 2014; Lawson 2012). Conversely, resource exchange for commercially important aquaculture species generally flows from South to South or North to South (Bartley et al. 2009). Structural developments of the aquaculture sector are leading to fewer and larger companies, so conflicts are likely to evolve between small and large-scale private actors rather than between countries (Rosendal et al. 2013). This means that the territorial focus of the CBD does not necessarily reflect the patterns of exchange and conflict when it comes to aquaculture genetic resources (Humphries 2016). Further, the free flow of migratory aquatic genetic resources between jurisdictional areas makes it difficult to pinpoint their origin for the territorial assumptions of ABS.

The CBD sets up the international ABS framework, while its supplementary agreement, the Nagoya Protocol on Access to Genetic Resources and the Fair and Equitable Sharing of Benefits Arising from their Utilization to the Convention on Biological Diversity (Nagoya Protocol or NP) sets out rules, procedures and compliance mechanisms to guide national implementation of ABS. The CBD applies to genetic resources within national jurisdiction and to processes and activities carried out by a country's nationals that are within its control or beyond the limits of its national jurisdiction (CBD article 4). The Nagoya Protocol only applies to resources within national jurisdiction (NP article 3). Some scholars argue that ABS obligations do not apply to the use of genetic resources that were

\footnotetext{
1 This analysis focuses on sharing the physical genetic resources; however, even greater legal, ethical and political complexities arise from accessing and using the digital resource the information about genetic resources such as DNA sequencing information) (UN Doc 2016); these are beyond the scope of this article.
} 
deposited in an ex situ facility before the CBD (1993) or Nagoya Protocol (2014) entered into force, while others argue that access and benefit sharing may capture new and continuing uses of these resources (Biber-Klemm et al. 2015; Greiber et al. 2012). This is often a matter for local law to decide.

Both agreements apply to 'genetic resources' used for their 'genetic material' ${ }^{2}$ value (for example, for breeding or pharmaceutical product development) and not for other values such as commodities for consumption. Under the ABS provisions, countries control access to genetic resources sourced from their jurisdiction (CBD article 15(3)) but under domestic law may have a number of access providers entitled to prior informed consent before a resource user can collect a resource. In return, users must share, under mutually agreed terms (usually through a benefit-sharing agreement) with the provider, the results of research and development and the benefits they derive from the 'utilization of genetic resources', including technology transfer (CBD article 15(7)). The provider who is entitled to the right of prior informed consent and access on mutually agreed terms can be the 'country of origin' (those possessing the genetic resources in in situ conditions) or the 'country providing genetic resources' (from wild or domesticated sources) that have acquired genetic resources 'in accordance with the Convention' (CBD articles 2, 15(3)). Under the CBD's stand-alone technology transfer provisions, Contracting Parties must facilitate access to and transfer of technologies that 'make use' of genetic resources to other Contracting Parties to the CBD (CBD article 16). They also have obligations for information sharing and cooperation (CBD articles 12, 17 and 18), participation and capacity building (article 19) and funding for technology transfer in developing countries (CBD article 20).

The United Nations Convention on the Law of the Sea (UNCLOS) applies to 'living resources' (not explicitly to 'genetic resources') both within and beyond national jurisdiction. UNCLOS establishes a legal order for the marine environment but does not have distinct ABS obligations. Instead, it promotes the 'equitable and efficient utilization of [sea and ocean] resources' (preamble) including through a patchwork of obligations for technology transfer (Part XIV) and knowledge sharing from marine scientific research (Part XIII). These obligations span the maritime zones within national jurisdiction and in areas beyond national jurisdiction (ABNJ) that comprise high seas waters and seabed. The obligations include a duty to cooperate to promote the development and transfer of marine science and technology on fair terms for the benefit of all parties concerned and to promote the technological capacity of countries, particularly developing countries, to explore, exploit, conserve and management marine resources (article 266). Countries must also disseminate knowledge resulting from marine scientific research (article 244(1)). This includes actively promoting the transfer of resulting knowledge, particularly to developing countries, as well as building developing countries' capacities to develop their own research and technologies (articles 244(2), 143(3)). In recognition of the increasing commercial interest in high seas aquatic genetic resources that are not captured by the CBD's framework, the international community is negotiating a legally binding Implementing Agreement under UNCLOS, which will attempt to clarify ABS obligations concerning ABNJ genetic resources (Ad Hoc Open-ended Informal Working Group 2015).

The Antarctic Treaty Area (the area south of $60^{\circ}$ south latitude) is a distinct third jurisdictional area because it is neither fully within nor beyond national jurisdiction. Rather,

\footnotetext{
${ }^{2}$ Genetic resources means 'genetic material of actual or potential value'; genetic material means 'any material of plant, animal, microbial or other origin containing functional units of heredity'; CBD article 2.
} 
it has its own unique arrangements where territorial claims are on hold and governance is dependent on cooperation between representatives of Contracting Parties to the Antarctic Treaty through the Antarctic Treaty Consultative Meeting (Antarctic Treaty article IV). While no country has jurisdiction over Antarctica's in situ resources, countries have authority to regulate the activities of their observers, scientific personnel and staff in Antarctica (article VIII(1)), including activities falling within their national ABS and patent laws.

The Antarctic Treaty System including the Antarctic Treaty, the Protocol on Environmental Protection to the Antarctic Treaty (Madrid Protocol) and the Convention on the Conservation of Antarctic Marine Living Resources (CCAMLR) regulates activities in the Antarctic Treaty Area. None of the treaties define or explicitly govern ABS of Antarctic genetic resources (ATCM 2009). Instead, there are general obligations to access in situ resources in accordance with the principle of freedom of scientific investigation and cooperation (article II), upon prior notification to other Contracting Parties and in some cases, through permit applications (Antarctic Treaty article VIII(5); Madrid Protocol Annex II article 3(1); ATCM 2005). As a form of global 'benefit sharing', the system supports the continuance of freedom of scientific investigation and cooperation and requires the exchange and free availability of 'scientific observations and results' (Antarctic Treaty article III; Madrid Protocol article 17, CCAMR article XX). These access and technology transfer provisions do not apply to ex situ Antarctic genetic resources (ATCM 2009), nor do they apply to countries outside the Antarctic Treaty System.

Exclusive rights under national intellectual property laws add another layer of complexity to sharing aquatic genetic resources and are implicitly or explicitly recognized under the above instruments. Access, technology transfer and benefit sharing under the CBD and Nagoya Protocol must take into account all rights over the relevant resources and technologies, including intellectual property (CBD article 1; Nagoya Protocol articles 1 and 3). UNCLOS technology transfer obligations are subject to having due regard for all 'legitimate interests' (UNCLOS article 267) and 'legitimate uses' (article 240(c)), which are undefined but are likely to include proprietary interests under intellectual property law (Humphries 2017b). The Antarctic Treaty is silent on its interaction with intellectual property and while some participants in the ATCM have expressed concerns about its compatibility with treaty objectives (ATCM 2009), applicants continue to claim patents over inventions containing Antarctica's genetic resources (ATCM 2008).

Patenting genetic resources for use in aquaculture is in its early stages. As a generalization, the majority of aquaculture genetic resources are freely exchanged or sold without further conditions attached (Louafi and Schloen 2013). However, as a means of recouping the costs of investment, protecting the knowledge of genetic resource inventions with patent claims is likely to attract more interest, particularly where biotechnology is involved. Under the World Trade Organization's (WTO) Trade-Related Aspects of Intellectual Property Rights (TRIPS), WTO members are bound to minimum standards of intellectual property protection, including an obligation to make exclusive patent rights (up to 20 years) available for any invention, under certain conditions, subject to some optional exclusions from patentability (articles 27 and 33). The law on patentability of genetic resources is evolving to keep up with new genetic resource technologies. ${ }^{3}$ Exclusions

\footnotetext{
${ }^{3}$ For example, the Australian High Court found that an isolated nucleic acid coding for certain mutations in the human BRACA1 polypeptide was not a patentable invention within the meaning of s 18(1)(a) of the Patents Act 1990 (Cth); D'Arcy v Myriad Genetics Inc (2015) 89 ALJR 924.
} 
from patentability, however, can often be overcome by clever claim drafting (Bently et al. 2010). Concerns have long been expressed that broad patent claims relating to genetic resources could restrict access to the physical and digital resource for further research and direct the benefits towards a patent holder rather than the provider of the genetic resource (Jabour-Green and Nicol 2003). However, defences against infringement (Sect. 5 below) can play an important role in balancing private interests with the public interest in sharing knowledge for the benefit of technological development and the conservation of genetic resources.

\section{Pinpointing the geographical origins of tilapia genetic resource products}

Tilapias originated from Africa and the Middle East and include over 70 species (Xia et al. 2015). They are now cultured in over 100 countries outside of their native Africa, mainly in Asia (Eknath and Hulata 2009), and their production has increased dramatically (FAO 2017). Their popularity as a cultured stock is largely due to their efficient use of low protein (inexpensive) diets, high fecundity and high tolerance to a wide range of environmental conditions, stress and infections (Hassanien et al. 2005). A key factor in the growth of tilapia culture was the regional research and development programme 'Genetic Improvement of Farmed Tilapia' (GIFT) under the leadership of WorldFish (the International Centre for Living Aquatic Resources Management or ICLARM). In 1988, eight populations of Nile tilapia-comprising wild Nile tilapia populations from Africa and domesticated populations used in Asia that also included the species Oreochromis mossambicus-were collected to form part of the genetic base of the GIFT strain (Gupta and Acosta 2004). Researchers used a genetically mixed base population including pure bred and crossbred groups for the subsequent selective breeding (genetic improvement) programme that resulted in superior genetic gain for selected traits in the GIFT strain compared with the base population. WorldFish distributed GIFT germplasm freely to 11 countries in Asia and the Pacific under material transfer agreements (Gupta and Acosta 2004). Since then, many countries have used this stock to produce tilapia suited to their local conditions. For example, the Philippines developed a new synthetic base population called GET-EXCEL using a GIFT strain, a non-GIFT domestic strain and wild strains originally collected by GIFT partners (Tayamen 2004).

With the advent of biotechnology advances, there is more opportunity for developing aquaculture products that incorporate genetic material from different jurisdictional areas. Researchers are experimenting with transgenic tilapias using DNA from species found in areas spanning national jurisdiction, ABNJ and Antarctic waters, such as from spiny dogfish (El-Zaeem and Assem 2004) and cold ocean teleost fishes (Lee et al. 2011). One transgenic tilapia awaiting regulatory approval for commercialization ${ }^{4}$ was produced by using a chinook salmon growth hormone gene that was spliced to a cold ocean teleost fishes' antifreeze gene promoter, co-ligated to a carp reporter gene construct and integrated into a Nile

\footnotetext{
${ }^{4}$ Rasmussen and Morrissey 2007 p. 5. A similar construct for salmon has already been approved for commercialization; see http://www.fda.gov/AnimalVeterinary/DevelopmentApprovalProcess/GeneticEngineer ing/GeneticallyEngineeredAnimals/ucm280853.htm and sold for the first time in August 2017: Emily Waltz, First Genetically Engineered Salmon sold in Canada (2017) Scientific American https://www.scien tificamerican.com/article/first-genetically-engineered-salmon-sold-in-canada/.
} 
tilapia genome to produce a tilapia with a superior growth trait (Caelers et al. 2005). Transgenic processes generally involve introducing the DNA construct (growth hormone) along with a promoter sequence (antifreeze gene promoter) into the pronuclei of fertilized eggs, which are then implanted into the host's uterus and grown out (Rasmussen and Morrissey 2007). Research has shown that incorporation of this construct into the organisms' genome results in transgene expression in subsequent generations of tilapia (Maclean et al. 2002).

Interesting legal questions for ABS arise if a transgenic fish incorporates genetic material from more than one jurisdiction, given that ABS laws are different in each country depending on how they have implemented their international obligations. Each relevant law would need to be analysed on a case-by-case basis to determine the nature of resources and scope of use that falls within ABS, who is entitled to a right of consent for access, the conditions of access and utilization, and who is entitled to share the benefits of their use. Analysis of national laws is beyond the scope of this paper, which examines the international regime level. However, important ethical and legal issues arise from the application of multiple regimes to the same aquatic biological resource, namely the difficulty for ensuring that the original provider jurisdiction obtains some benefits from the resources' subsequent uses to achieve the fairness and conservation objectives of compensating those who bear the costs of conserving the wild resources.

A hypothetical example explained below illustrates the complexity of determining who should obtain the benefits of genetic resource use. The reason for using a hypothetical, rather than a real example is the difficulty of obtaining documented information on the actual origins of aquatic genetic resource components of a transgenic product. The Nagoya Protocol's ABS Clearing House mechanism is designed to capture some of this information (NP article 14). However, it is in the early stages of its implementation, as are national ABS laws and systems that may track this information. Due to the high costs of investing in transgenic technologies, developers are likely to also protect their information through confidentiality agreements or intellectual property. There has been significant international debate about whether to amend TRIPS to include a mandatory requirement for disclosure of origin for patent applications containing genetic resources and/or associated traditional knowledge to act as a safeguard against misappropriation and to ensure the correct provider countries obtain benefits (e.g. WTO Doc 2011). The difficulties with documenting and tracing genetic resource origin underlie a more fundamental challenge than the lack concrete examples for legal analysis. It challenges the usefulness of the CBD's approach to ABS that hinges on determining the jurisdictional origin of a particular resource.

Turning to the hypothetical example, an inventor of a transgenic tilapia product might seek materials from within national jurisdiction (e.g. GET-EXCEL tilapia), ABNJ (e.g. ex situ Chinook growth hormone material) and Antarctic waters (e.g. ex situ antifreeze gene promoter material from cold ocean fishes). If the country where the materials are obtained has implemented national laws in accordance with the CBD and Nagoya Protocol, the user would need to enter into a benefit-sharing agreement with the resource access provider as a condition of access. The provider is usually the government or another individual or entity in control of the biological resource. In the case of the GET-EXCEL component, provider countries could include Africa (where the wild tilapia strain came from) and the Philippines (where the domesticated strain developed its distinctive properties). ${ }^{5}$ However, whether Africa would receive the benefits depends on the timing and location

\footnotetext{
${ }^{5}$ See definition of in situ resources under CBD article 2.
} 
of the accession. If the inventor takes GIFT material from a repository holding the material before 1993, the CBD obligations might not apply, depending on the laws where the repository is located (see part 2 above). If the inventor takes non-GIFT tilapia strain from African waters after 1993, the African provider might claim entitlement to benefit sharing. However, as the GET-EXCEL strain already incorporates pre-CBD materials, it is unlikely that Africa would have a strong claim. If the strain came from a land based ex situ repository, the intermediary or the provider (in this case the Philippines) might claim entitlement depending on the contractual arrangements between the parties. UNCLOS provisions might apply if the strain is held in a natural body of water in which case the Philippines could be entitled to consent for access and the benefits of technology transfer. If a country is only committed to UNCLOS obligations and not the CBD, there is no requirement to share the benefits of Nile tilapia's use in subsequent strains with Africa as the country of origin. UNCLOS does, however, encourage countries to share knowledge and technologies generally with other countries.

In the case of the other genetic material components of the 'invention', depending on contractual arrangements with the ex situ repository holding the Chinook genetic materials, there may be no requirement to share the benefits from its use with the jurisdictions of origin, including several countries and the high seas. This is because of the difficulty of pinpointing the origin of the resource. There is no global multilateral mechanism to regulate such cases as envisaged by the Nagoya Protocol (article 10). It is likely that an inventor would argue that the material was taken from the high seas where the Nagoya Protocol does not apply. UNCLOS does not yet have an Implementing Agreement that regulates high seas resource use. Instead, the country where the ex situ repository is located may claim that they are the providers for the purposes of the Nagoya Protocol framework that applies to a transaction within their country and seek to obtain the benefits of further use of the materials (see Humphries 2018). Likewise, there would be no requirement for Antarctica to benefit from the use of its antifreeze gene promoter genetic resource but rather, the country authorising the relevant access or the country in which the genetic resource is stored may claim the benefits of further use (Humphries 2018). For any subsequent use of the hypothetical transgenic invention, the most straightforward claim for benefits from use of the genetic resource would be by the patent holder of either the transgenic fish or a patented product within the transgenic fish. These jurisdictional considerations illustrate some of the difficulties for ensuring that the user of a biological resource compensates the provider by sharing the benefits of the resource's use.

As more than one ABS regime can apply to the same genetic resource product, questions of prioritization arise where there are inconsistent obligations under the various instruments. The CBD and Nagoya Protocol must cede to any existing international agreements (including the Antarctic Treaty) unless there is likely to be a 'serious damage or threat to biological diversity', in which case, the CBD's provisions prevail (CBD article 22(1); Nagoya Protocol article 4(1)). The threshold for harm is undefined and would need to be assessed on a case-by-case basis (Glowka 1994). Parties must implement the CBD consistently with countries' rights and obligations under the law of the sea (UNCLOS article 22(2)) which means UNCLOS would prevail in cases of conflict with the CBD (Glowka 1994). UNCLOS does not alter the rights and obligations of other instruments compatible with UNCLOS (article 311(2)); for example, the Antarctic Treaty. TRIPS entered into force after the CBD, UNCLOS and Antarctic Treaty (but before the Nagoya Protocol). To the extent of any inconsistency concerning patented genetic resources, the ordinary principles of international law are likely to apply. In other words, where two or more treaties deal with the same subject matter but have differing provisions the terms of the more recent 
treaty will prevail unless there are express provisions to the contrary (Vienna Convention on the Law of Treaties article 30).

\section{Playing 'chicken' in the sea}

The duplication of ABS arrangements over the same trans-jurisdictional genetic resource and the temptation for forum shopping or opting out of various agreements has arguably led to a game of 'chicken'. The game of chicken is a model of conflict in game theory. Theorist uses the theory to predict how players will behave in their own interests when conflict arises (Mandani 2010). Generally, it is explained by the analogy of two players who are in separate cars driving on opposite sides of the road towards a head-on collision. The principle of the game is that while both players benefit if the other player yields, their own optimal choice is dependent upon the action of their opponent. If their opponent yields, it is better to maintain the course. If their opponent fails to yield, they must collide or yield and lose face. Chicken (or 'dove/hawk') game theory has been used to understand animal behaviour in a variety of fields such as biological sciences (Kaveh et al. 2016), natural resource management (Mandani 2010), and negotiations for environment (Attanasi et al. 2012) and climate change (Wood 2011) treaties. This section draws an analogy in the context of conflicting interests over genetic resource use and exchange caused by the predominant jurisdictional area approach to ABS, using the hypothetical transgenic tilapia example above. It is not intended to be an analysis of the theory itself.

At the heart of any conflict over the fair use and exchange of aquatic genetic resources is the protection of interests. The mechanism for balancing interests under ABS is a transactional arrangement between users and providers where the user shares the benefits with the provider who is responsible for the conservation of the genetic resource. This seems logical if the subject of the transaction, for example a plant genetic resource, is limited to a particular jurisdictional area. However, the genetic chain of custody becomes more complicated where domesticated and modified genetic resources incorporate other genetic resources with different countries of origin. It becomes even more complicated where the genetic resource has no country of origin, such as ABNJ, Antarctic, digital genetic resources and ex situ resources of unknown origin.

Arguably, this transactional and jurisdictional (territorial) approach to ABS tempts countries to play the game of chicken when it comes to sharing trans-jurisdictional aquatic genetic resources. In the game of 'aquatic chicken', a player (country) is faced with three choices when managing aquatic genetic resource use and knowledge. The first choice is that it maintains its course towards protecting its national interests by opting out of ABS obligations and keeping all of the benefits of the resources' use, while the other players yield and bear the costs of access, use and conservation of the genetic resources. A player in this position obtains the benefits of resource use without the responsibility to share knowledge and other benefits to conserve the genetic resources.

If a player fails to yield, the second choice is to either collide with the unyielding player by also opting out of ABS obligations (in effect, returning to a 'free for all' situation prior to the CBD). Alternatively, they can yield and bear their own ABS burden as well as the costs of free riders who enjoy the benefits of the system but who do not bear the costs of benefit sharing with others. There is of course another choice where players cooperate so that all players yield by surrendering some of their interests on a fair and equitable basis, meaning that each player does not carry a disproportionate burden. In this case, players would ratify all of the relevant ABS instruments and cooperate to share the benefits in 
accordance with the original ABS concept so that the users of the biological resources compensate the countries responsible for their conservation.

However, even if unanimous cooperation was possible, the transgenic example indicates that the transactional and jurisdictional nature of the game is a serious flaw when dealing with aquatic genetic resources. In this case, users who play by the rules are not obliged to share the benefits of their use to help conserve wild tilapia genetic resources from Africa and the Middle East, or chinook salmon genetic resources of multiple countries and the ABNJ, or cold ocean teleost fishes of the Antarctic Treaty Area. Given that the majority of aquaculture programs require regular inputs from migratory wild stocks to prevent inbreeding depression (Gjedrem 2012), it is crucial for the future of the sector to find knowledge sharing mechanisms that benefit the conservation of wild stocks. The jurisdictional basis of ABS has created the narrow road in the game of chicken where countries are either in or out of ABS obligations. Perhaps it is time to find a new game with broader parameters so that even those who maintain the course of over-riding national interest are encouraged to share knowledge for the benefit of genetic resource conservation.

\section{A cooperative purpose-based approach to sharing tilapia genetic resources}

In recognition of the transactional and territorial limitations of ABS, the Nagoya Protocol requires parties to consider the possible development of a 'global multilateral benefitsharing mechanism' for resources in 'transboundary situations or for which it is not possible to grant or obtain prior informed consent' (Nagoya Protocol article 10). Discussed below are existing examples of multilateral mechanisms that provide a model for aquatic genetic resources- the Food and Agriculture Organization of the United Nations' International Treaty on Plant Genetic Resources for Food and Agriculture ('Plant Treaty') and the World Health Organization's (WHO's) Pandemic Influenza Preparedness Framework for the Sharing of Influenza Viruses and Access to Vaccines and Other Benefits ('PIP') (World Health Assembly 2011). Unlike the CBD's proprietary bilateral approach where the provider is responsible for access as well as being the recipient of benefits that flow from their subsequent use, the purpose-driven cooperative approaches under these mechanisms break the ABS territorial nexus so that the provider country grants access but the benefits flow to the collective to achieve a particular goal. These mechanisms are less vulnerable to the game of chicken because even if a country does not ratify or comply with one of the mechanisms, private actors such as gene repositories can participate independently in the ABS system and direct the benefits of a resources' use to fulfil a conservation or research purpose.

Under a cooperative approach, the Plant Treaty creates a multilateral system of access and benefit sharing for a negotiated selection of plant genetic resources used for food and agriculture (Plant Treaty article 10). The agreement obliges each member to promote an integrated approach to the exploration, conservation and sustainable use of plant genetic resources for food and agriculture, including supporting local efforts to manage and conserve them on-farm (article 1(c)) and promoting in situ conservation of wild relatives (article 5(1)(d)). Members, in exercise of their sovereignty, provide access to each other's plant genetic resources for research, breeding, conservation and training, subject to benefit-sharing arrangements (article 10(2)) in the areas of information exchange, technology transfer and capacity building (non-monetary benefits) and commercial development (article 13). 
They have an opportunity for sharing monetary benefits through the funding mechanism (article 19(3)(f)). If a recipient chooses to prevent others from using for their own research and breeding any product they develop using the materials from the system, they must share a percentage of their commercial benefits to the fund (it also encourages other voluntary payments) (article 13(2)(d) and 13(6)). The monetary and non-monetary benefits arising from the use of shared plant genetic resources for food and agriculture should flow primarily-directly and indirectly - to farmers in all countries, especially in developing countries and countries with economies in transition, who conserve and sustainably use plant genetic resources for food and agriculture (article 13(3)).

The Plant Treaty is restricted to listed plant genetic resources but may have future relevance for aquatic plant genetic resources if they are included in the list. ${ }^{6}$ Many scholars suggest using the multilateral system under the Plant Treaty as a model for the exchange and use of aquatic animal genetic material, particularly from ABNJ (Greiber et al. 2011). The utility of this model for bypassing the game of chicken is that while countries can avoid ratifying the agreement so that they are not bound by its obligations, people and organizations have the opportunity to include genetic resource deposits in the system and be bound by its benefit-sharing mechanism (article 15(1). This means that in the case of an ex situ facility, unlike the outcome identified above for the jurisdictional and transactional approach under the CBD, generally it is not the provider (or the country in which the provider is located) that benefits from the use of the genetic resources. Rather, the benefits can flow to build the technological capacity of developing countries and support the conservation of wild and modified plant genetic resources in situ.

The PIP framework is another example of a multilateral mechanism for sharing benefits towards a particular purpose, rather than provider countries per se. The system is not directly relevant to aquatic genetic resources because it only applies to the sharing of H5N1 and other influenza viruses with human pandemic potential (PIP article 3). However, it provides an interesting model that integrates the sharing of physical resources, data, information as well as knowledge (articles 5.2 and 6.13.4). Its objective is to improve pandemic influenza preparedness and response and to strengthen the WHO Global Influenza Surveillance and Response System with the aim of fairly and equitably sharing H5N1 and other influenza viruses with human pandemic potential as well as access to vaccines and sharing other benefits (article 2). In achieving its objective, it recognizes 'the sovereign right of States over their biological resources and the importance of collective action to mitigate public health risks' (article 1(11)). The PIP framework requires, as an element of benefit sharing, an annual partnership contribution for those accessing the ex situ materials for improving global pandemic influence preparedness and response (article 6.14.3). Some of the non-monetary benefits include the transfer of technology, skills, know-how ${ }^{7}$ and in some cases, vaccines (articles 6.13 and annex 2). The PIP framework differs from the Plant Treaty because it automatically applies to all WHO members rather than taking the form of a treaty requiring ratification before its obligations apply to a country. This means that a country would need to opt out of the WHO if they did not want to be bound by the framework's obligations. The framework also binds private entities that obtain materials

\footnotetext{
6 The definition of 'plant genetic resources for food and agriculture' under Plant Treaty article 2 is broad enough to include aquatic plants and while none are included in Annex 1 to which the multilateral system applies, non-Annex 1 materials may be included in the system (Plant Treaty article 15).

7 PIP framework article 6.13.
} 
from the multilateral system, which can also circumvent the effects of a country playing 'chicken' (opting out of the PIP framework) with the genetic resources in question.

Another purpose-based cooperative approach is the patent law defence framework set up by the TRIPS agreement. An important counterbalance to the granting of exclusive rights over genetic resource inventions under TRIPS is this system of defences, which can help achieve TRIPS' technology transfer objectives. These objectives are;

The protection and enforcement of intellectual property rights should contribute to the promotion of technological innovation and to the transfer and dissemination of technology, to the mutual advantage of producers and users of technological knowledge and in a manner conducive to social and economic welfare, and to a balance of rights and obligations (TRIPS article 7).

World Trade Organization Members' defences must comply with their TRIPS obligations including under article 30 ('three step test' for exceptions), ${ }^{8}$ article 6 (exhaustion) and article 31 (requirements for compulsory licences). Common exceptions of relevance to aquaculture include experimental use, breeding, regulatory approval, non-commercial use, farmer's privilege, and innocent bystander exceptions (Humphries 2015).

WTO members have flexibility about how they implement their TRIPS obligations, including using defences to suit their technological needs. For example, some members have a narrow experimental use exception, only allowing the investigation of a patented genetic resource invention for the purposes of testing and further developing the invention (experimenting 'on' the invention) (Australian Law Reform Commission 2004). This would not allow the use of some genetic materials such as patented gene promoters (like the AFP in the transgenic tilapia example) because the material itself is not being investigated, but rather is being used as a research tool to introduce the chinook salmon growth hormone gene into the tilapia genome (Prifti 2013). The latter would require a broader experimental use defence that allows experimenting 'with' the invention. This would allow investigation not only of the invention itself but also allow its use as a tool to investigate a gene and its expression (experimenting 'with' the invention). For those countries with good biotechnological infrastructure such as the USA and other developed countries, a narrow defence is advantageous for protecting investment in genetic resource inventions. For those seeking to build their knowledge and technological capabilities, such as African countries, a broader defence can give breeders and researchers greater access to patented genetic resources and knowledge used within their jurisdiction without a licence (Humphries 2015). Such knowledge can strengthen their research capacity not only for tilapia product development but also for sharing techniques and knowledge for conserving their wild stocks.

In summary, these cooperative approaches may lead to fairer outcomes for transboundary genetic resource use and benefit sharing. This is particularly the case where one of the greatest benefits of genetic resource use is the sharing of knowledge 'in the interests of science and the progress of all [hu]mankind' as envisaged by the Antarctic Treaty System of cooperative governance (Antarctic Treaty preamble). The benefits of the cooperative approach for aquatic resource sharing in Antarctica have been argued elsewhere (Humphries 2018). There are early indications that the proposed Implementing Agreement under

\footnotetext{
8 The three-step test requires that exceptions must: (a) be limited in their impact on rights; (b) 'not unreasonably conflict with a normal exploitation of the patent'; and (c) 'not unreasonably prejudice the legitimate interests of the patent owner, taking account of the legitimate interests of third parties'; TRIPS article 30.
} 
UNCLOS for ABS of high seas genetic resources may incorporate a cooperative approach to sharing knowledge, resources as well as the costs of conservation. For example, the Preparatory Committee met in 2016 and 2017 to develop recommendations for the development of a draft text by a United Nations Intergovernmental Conference (United Nations General Assembly 2017). It recommended that the text would take into account the special requirements of certain countries 'to avoid a disproportionate burden of conservation action onto developing countries' (A.III.1).

\section{Conclusion}

'Aquatic chicken' or 'tilapias' are likely to become the most important of all cultured fishes in the twenty-first century (Tran et al. 2011). Yet there are limited data about the genetic characterization of their natural populations (Ndiwa et al. 2016). This knowledge is necessary not only for the conservation of wild stocks and the prevention of inbreeding depression of cultured stocks, but also for the development of new tilapia products suited to local conditions. The original ABS concept embraced the idea that monetary and non-monetary benefits (including technologies and know-how) would flow to the countries that have responsibility for the conservation of genetic resources and help build their research capacity to protect wild stocks and develop new strains to suit their local conditions. However, the CBD's simplistic transactional approach based on territorial jurisdiction creates the reverse outcome in more complex situations involving multiple providers who share multiple resources from multiple jurisdictions. In the case of trans-jurisdictional aquatic genetic resources where stocks straddle state jurisdictions, ABNJ and the Antarctic Treaty Area, there is likely to be no single 'provider' who can be held responsible for the resources' physical conservation. It would be difficult to legally compel users of the genetic resources in question to direct the benefits towards conservation in the resources' area of origin, including developing countries. As a consequence, sharing the burden for conservation in a fair and equitable way has been removed from the ABS transaction.

Perhaps the most obvious flaw of the jurisdictional approach to ABS is that it promotes the optimal choice in the game of 'aquatic chicken' of maintaining the course of over-riding national interest, which forces the other players to yield and bear their own ABS burden as well as the costs of free riders. However, this article argued that players could look to broader agreements, including economic agreements, for mechanisms to involve 'free riders' in technology transfer. One mechanism is the TRIPS compliant patent law defence framework, which may result in the sharing of genetic resource knowledge, regardless of whether the country of origin has ratified an ABS agreement. Arguably some of the defences have the effect of a purpose-driven cooperative approach to knowledge sharing that can achieve ABS objectives.

Purpose-driven cooperative approaches break the ABS territorial nexus, so that a provider country grants access but the benefits flow to the collective to achieve a particular goal. This approach is based on the concept of fairness where private and public interests are balanced not only between each other, but also with the objective of supporting a particular purpose. The approach is gaining traction under multilateral agreements such as the Plant Treaty and the PIP framework used for ABS of limited plant and virus genetic resources, respectively. While countries may still opt out of these agreements, private actors and supranational organizations may opt in and contribute to directing the benefits towards fulfilling a purpose, including conservation goals and capacity building in the countries of origin of the wild stocks. Employing a similar approach for aquatic genetic 
resources, including tilapia, could have the effect of giving players and bystanders another option in the game of chicken-to bypass the political game entirely and share the benefits for conservation of biological resources that straddle multiple areas of origin. In this way, moving away from the territorial jurisdictional approach of ABS towards a cooperative purposive approach could facilitate a more equitable sharing of knowledge and materials for aquatic genetic resource conservation, product development and capacity building in their areas of origin.

Acknowledgements I thank Professor Charles Lawson for his comments on this article. I also thank Griffith University for funding the writing of this article.

\section{Compliance with ethical standards}

Conflict of interest After researching and drafting this article, the WorldFish Center engaged the author to carry out a research consultancy on aquaculture. WorldFish is an aid and development organization based in Malaysia and was central to the dissemination of tilapia GIFT genetic resources mentioned in the article. The work in this article was not a result of (not funded by) the WorldFish consultancy.

\section{References}

Ad Hoc Open-Ended Informal Working Group. (2015). Letter dated 13 February 2015 from the Co-Chairs of the Ad Hoc Open-Ended Informal Working Group to the President of the General Assembly. (69th sess, Agenda Item 74(a), UN Doc A/66/780, 13 February 2015).

Antarctic Treaty, opened for signature Dec. 1, 1959, in force June 23, 1961, 402 U.N.T.S. 71 ('Antarctic Treaty') Art. VI.

Antarctic Treaty Consultative Meeting-ATCM. (2009). A gap analysis of the antarctic treaty system regarding the management of biological prospecting (32nd mtg, Agenda Item 17, WP 26, April 2009).

Antarctic Treaty Consultative Meeting-ATCM. (2008). An update on biological prospecting in Antarctica, including the development of the antarctic biological prospecting database (31st $\mathrm{mtg}$, Agenda Item 17, WP 011, June 2008).

Antarctic Treaty Consultative Meeting-ATCM. (2005). Decision 10, electronic information exchange system (28th mtg, Agenda Item 17, adopted 17 June 2005).

Aoki, K., \& Luvai, K. (2007). Reclaiming common heritage treatment in the international plant genetic resources regime complex. Michigan State Law Review, 35, 35-70.

Attanasi, G., Gallego, A., Georgantzís, N., \& Montesano, A. (2012). Environmental agreements as a HawkDove game with confirmed proposals. Environmental Economics, 3(4), 35-42.

Australian Law Reform Commission. (2004). Genes and ingenuity: Gene patenting and human health (Report No. 99, 2004).

Bartley, D., et al. (2009). The use and exchange of aquatic genetic resources for food and agriculture (Background Study Paper No. 45, 2009).

Bently, L., et al. (2010). Experts' study on exclusions from patentable subject matter and exceptions and limitations to the rights (World Intellectual Property Organization Standing Committee on the Law of Patents, 15th sess, WIPO Doc SCP/15/3, 2 September 2010) annex 1 ('Introduction').

Biber-Klemm, S., Davis, K., Gautier, L., Kiehn, M., \& Martinex, S. (2015). Ex situ collections of plants and how they adjust to ABS conditions. In E. Kamau, G. Winter, \& P.-T. Stoll (Eds.), Research and development on genetic resources: Public domain approaches in implementing the Nagoya protocol (pp. 207-225). London: Routledge.

Caelers, A., et al. (2005). Expression of endogenous and exogenous growth hormone (GH) messenger (m) RNA in a GH-transgenic tilapia (Oreochromis niloticus). Transgenic Research, 14(1), 95-104.

Convention on Biological Diversity, opened for signature June 5, 1992, in force Dec. 29, 1993, 1760 U.N.T.S. 79.

Convention on the Conservation of Antarctic Marine Living Resources, opened for signature May 20, 1980, in force April 7, 1982, 1329 U.N.T.S. 47.

Eknath, A., \& Hulata, G. (2009). Use and exchange of genetic resources of Nile tilapia (Oreochromis niloticus). Reviews in Aquaculture, 1(3-4), 197-213. 
El-Zaeem, S., \& Assem, S. (2004). Application of biotechnology in fish breeding: production of highly immune genetically modified Nile tilapia, Oreochromis Niloticus with accelerated growth by direct injection of shark DNA into skeletal muscles. Egyptian Journal of Aquatic Biological and Fisheries, 8(3), 67-92.

Food and Agriculture Organization of the United Nations. (2016). The state of world fisheries and aquaculture: Contributing to food security and nutrition for all. http://www.fao.org/3/a-i5555e.pdf. Accessed 24 May 2018.

Food and Agriculture Organization of the United Nations. (2017). Oreochromis niloticus; Cultured aquatic species information programme. http://www.fao.org/fishery/culturedspecies/Oreochromi s_niloticus/en. Accessed 24 May 2018.

Frison, C., López, F., \& Esquinas-Alcazar, J. (Eds.). (2012). Plant genetic resources and food security: Stakeholder perspectives on the international treaty on plant genetic resources for food and agriculture. London: Routledge.

Gjedrem, T. (2012). Genetic improvement for the development of efficient global aquaculture: A personal opinion review. Aquaculture, 344, 12-22.

Glowka, L. (1994). A guide to the convention on biological diversity (Environmental Policy and Law Paper No. 30, International Union for the Conservation of Nature).

Greiber, T., et al. (2011). Access and benefit sharing in relation to marine genetic resources from areas beyond national jurisdiction: A possible way forward (Study Paper, Federal Agency for Nature Conservation)

Greiber, T., et al. (2012). An explanatory guide to the Nagoya protocol on access and benefit-sharing (Environmental Policy and Law Paper No. 83, International Union for Conservation of Nature).

Gupta, M. V., \& Acosta, B. O. (2004). From drawing board to dining table: the success story of the GIFT project. NAGA, WorldFish Center Quarterly, 27(3-4), 4-14.

Hassanien, H. A., \& Gilbey, J. (2005). Genetic diversity and differentiation of Nile tilapia (Oreochromis niloticus) revealed by DNA microsatellites. Aquaculture Research, 36(14), 1450-1457.

Humphries, F. (2015). Shellfish patents krill experimentation: Defences for sharing patented aquatic genetic materials in aquaculture. European Intellectual Property Review, 37, 210-224.

Humphries, F. (2016). The rising tide of access and benefit sharing in aquaculture. In N. Bankes, D. VanderZwaag, \& I. Dahl (Eds.), Aquaculture law and policy: International, regional and national perspectives (pp. 63-100). Cheltenham: Edward Elgar.

Humphries, F. (2017a). A patent defence approach to sharing aquaculture genetic resources across jurisdictional areas. The Journal of World Intellectual Property, 20(5-6), 221-238.

Humphries, F. (2017b). A stewardship approach to legitimate interests in deep sea genetic resources for use in aquaculture. University of New South Wales Law Journal, 40(1), 27-56.

Humphries, F. (2018). Banking on a patent solution for sharing ex situ genetic resources from Antarctic waters. In C. Lawson \& A. Kamalesh (Eds.), Biodiversity, genetic resources and intellectual property: Developments in access and benefit sharing (pp. 59-94). London: Routledge.

Intergovernmental Oceanographic Commission. (2003). 2003 Intergovernmental Oceanographic Commission criteria and guidelines on the transfer of marine technology. XXII session of the assembly of the Intergovernmental Oceanographic Commission. http://unesdoc.unesco.org/image s/0013/001391/139193m.pdf. Accessed 24 May 2018.

International Treaty on Plant Genetic Resources for Food and Agriculture, opened for signature Nov. 3 , 2001, in force June 26, 2004, 2400 U.N.T.S. 303.

Jabour-Green, J., \& Nicol, D. (2003). Bioprospecting in areas outside national jurisdiction: Antarctica and the Southern Ocean. Melbourne Journal of International Law, 4, 76-111.

Kaveh, K., Veller, C., \& Nowak, M. (2016). Games of multicellularity. Journal of Theoretical Biology, 403, 143-158.

Khaw, H., Ponzoni, R., \& Danting, M. (2008). Estimation of genetic change in the GIFT strain of Nile tilapia (Oreochromis niloticus) by comparing contemporary progeny produced by males born in 1991 or in 2003. Aquaculture, 275(1), 64-69.

Lawson, C. (2012). Regulating genetic resources: Access and benefit sharing in international law. Cheltenham: Edward Elgar Publishing.

Lee, J. K., Kim, Y. J., Park, K. S., Shin, S. C., Kim, H. J., Song, Y. H., et al. (2011). Molecular and comparative analyses of type IV antifreeze proteins (AFPIVs) from two Antarctic fishes, Pleuragramma antarcticum and Notothenia coriiceps. Comparative Biochemistry and Physiology Part B: Biochemistry and Molecular Biology, 159(4), 197-205.

Louafi, S., \& Schloen, M. (2013). Practices of exchanging and utilizing genetic resources for food and agriculture and the access and benefit sharing regime. In E. C. Kamau \& G. Winter (Eds.), Common 
pools of genetic resources: Equity and innovation in international biodiversity law (pp. 193-223). Abingdon, UK: Routledge.

Maclean, N., Rahman, M. A., Sohm, F., Hwang, G., Iyengar, A., Ayad, H., et al. (2002). Transgenic tilapia and the tilapia genome. Gene, 295(2), 265-277.

Mandani, K. (2010). Game theory and water resources. Journal of Hydrology, 381(3), 225-238.

Marrakesh Agreement Establishing the World Trade Organization, opened for signature April 15, 1994, in force Jan. 1, 1995, 1869 U.N.T.S. 3 annex 1C ('Agreement on Trade-Related Aspects of Intellectual Property Rights').

Nagoya Protocol on Access to Genetic Resources and the Fair and Equitable Sharing of Benefits Arising from their Utilization to the Convention on Biological Diversity, opened for signature Oct. 29, 2010, in force Oct. 12, 2014 [2012] A.T.N.I.F. 3.

Ndiwa, T. C., Nyingi, D. W., Claude, J., \& Agnèse, J. F. (2016). Morphological variations of wild populations of Nile tilapia (Oreochromis niloticus). Environmental Biology of Fishes, 99(5), 473-485.

Oberthür, S., \& Rosendal, G. K. (2014). Global governance of genetic resources: Background and analytical framework. In S. Oberthür \& G. K. Rosendal (Eds.), Global governance of genetic resources access and benefit sharing after the Nagoya Protocol (pp. 1-18). New York: Routledge.

Prifti, V. (2013). The breeding exemption in patent law: Analysis of compliance with Article 30 of the TRIPS Agreement. The Journal of World Intellectual Property, 16(5-6), 218-239.

Protocol on Environmental Protection to the Antarctic Treaty, opened for signature Oct. 4, 1991, in force 1998, 30 I.L.M. 1455.

Rasmussen, R. S., \& Morrissey, M. T. (2007). Biotechnology in aquaculture: Transgenics and polyploidy. Comprehensive Reviews in Food Science and Food Safety, 6(1), 2-16.

Rosendal, G. K., Olesen, I., \& Tvedt, M. W. (2013). Evolving legal regimes, market structures and biology affecting access to and protection of aquaculture genetic resources. Aquaculture, 402, 97-105.

Tayamen, M. M. (2004). Nationwide dissemination of GET-EXCEL tilapia in the Philippines. In R. Bolivar, G. Mair \& K. Fitzsimmons (Eds.), 6th international symposium on tilapia in aquaculture (Vol. 6), ISTA

Tran, L., Van Ding, T., Ngo, T., \& Fotedar, R. (2011). Tilapia. In R. Fotedar \& B. Phillips (Eds.), Recent advances and new species in aquaculture (pp. 318-333). Oxford: Wiley-Blackwell.

UN Doc. (2016). Decision XIII/16 digital sequence information on genetic resources. Conference of the parties to the convention on biological diversity. 13th mtg, UN Doc CBD/COP/DEC/XIII/16, 16 December 2016.

United Nations General Assembly. (2015). Development of an international legally-binding instrument under the United Nations Convention on the Law of the Sea on the conservation and sustainable use of marine biological diversity of areas beyond national jurisdiction. GA Res 69/292, UN GAOR, 69th sess, 96th plen mtg, Agenda Item 74(a), Supp No 49, UN Doc A/RES/69/292, 6 July 2015, adopted 19 June 2015.

United Nations General Assembly. (2017). Report of the Preparatory Committee established by General Assembly resolution 69/292: Development of an international legally binding instrument under the United Nations Convention on the Law of the Sea on the conservation and sustainable use of marine biological diversity of areas beyond national jurisdiction. Preparatory Committee, 4th sess, UN Doc A/ AC.287/2017/PC.4/2, 31 July 2017.

Vienna Convention on the Law of Treaties, opened for signature May 23, 1969, in force Jan. 27, 1980, 1155 U.N.T.S. 331.

World Health Assembly. (2011). Resolution 64.5 of 24 May 2011. pandemic influenza preparedness: Sharing of influenza viruses and access to vaccines and other benefits. Sixty-fourth World Health Assembly, WHA64/5, 2011. www.apps.who.int/gb/ebwha/pdf_files/WHA64/A64_R5-en.pdf. Accessed 29 September 2017.

Wood, P. J. (2011). Climate change and game theory. Annals of the New York Academy of Sciences, 1219(1), $153-170$.

Wood, A., \& Mayer, J. (2007). Changing the face of the waters: The promise and challenge of sustainable aquaculture. Washington, DC: World Bank.

WTO Doc. (2011) Draft decision to enhance mutual supportiveness between the trips agreement and the convention on biological diversity (WTO document TN/C/W/59 of 19 April 2011).

Xia, J. H., Bai, Z., Meng, Z., Zhang, Y., Wang, L., Liu, F., et al. (2015). Signatures of selection in tilapia revealed by whole genome resequencing. Scientific Reports, 5, 14168. 